\title{
ELEMEN BERNALAR: IMPLIKASI DAN AKIBAT-AKIBAT PADA INDIKATOR MENGANTISIPASI SERTA MENCARI SOLUSI TERHADAP MASALAH MELALUI METAKOGNISI
}

\author{
Duwi Nuvitalia
}

\begin{abstract}
Abstrak
Penelitian ini bertujuan untuk mengetahui kemampuan siswa dalam mengantisipasi serta mencari solusi terhadap masalah melalui metakognisi. Metode penelitian yang digunakan adalah R\&D. untuk mendapatkan data, instrument penelitian yang digunakan yaitu berupa tes kemampuan berpikir kritis pada indikator mengantisipasi serta mencari solusi terhadap masalah, lembar kegiatan siswa, dan lembar kerja siswa pada kegiatan laboratorium IPA. Hasil penelitian menunjukkan, bahwa siswa dapat menggunakan kemampuan bernalarnya melalui metakognisi. Selain itu, siswa dapat mencari solusi dalam memecahkan masalah di dalam kegiatan laboratorium IPA sesuai dengan logika atau penalaran siswa sendiri.
\end{abstract}

Kata Kunci : elemen bernalar, metakognisi. 


\section{PENDAHULUAN}

\section{Latar Belakang}

Kualifikasi pendidikan di setiap jenjang pada kurikulum 2013 menuntut siswa untuk dapat menggunakan kemampuan berpikirnya sendiri. Sebagai implementasinya adalah pemberlakuan scientific approach. Langkah-langkah pendekatan ilmiah (scientific approach) dalam proses pembelajaran meliputi menggali informasi melalui kegiatan pengamatan, bertanya, mencoba, kemudian mengolah data atau informasi, menyajikan data atau informasi, dilanjutkan dengan menganalisis, menalar, kemudian menyimpulkan, dan mencipta.

Pada kegiatan "mengasosiasi/ mengolah informasi/ menalar" dalam kegiatan pembelajaran sebagaimana disampaikan dalam Permendikbud Nomor 81a Tahun 2013, merupakan kegiatan memproses informasi yang sudah dikumpulkan baik terbatas dari hasil kegiatan mengumpulkan/eksperimen maupun hasil dari kegiatan mengamati dan kegiatan mengumpulkan informasi. Pada tahapan menalar, tidak semua siswa sadar bahwa mereka sedang melakukan kegiatan pembelajaran di kelas. Jika hal ini terjadi, maka capaian pembelajaran tidak akan tercapai karena siswa tidak memahami secara sadar apa yang sedang dilakukan. Salah satu konsep konstruktivisme yang digagas oleh Suparno (1997: 61) menyatakan bahwa pengetahuan tidak ditransfer dari guru ke siswa, guru bertindak sebagai fasilitator saja sedangkan siswa secara aktif bernalar dan menggunakan seluruh potensi dirinya. Salah satu strategi pembelajaran yang sejalan dengan konstruktivisme adalah pendekatan metakognitif. Metakognitif merupakan pengetahuan yang berhubungan dengan proses kognitif untuk menyelesaikan masalah. Cognition is concerned with what someone knows, metacognition with what people know about their knowledge (Flavel 1979, Europe Journal of Engineering Education). Metakognisi dapat mengkonstruksi hubungan antara pengetahuan awal dengan pengetahuan yang baru, menemukan strategi pemecahan masalah dan merefleksikan proses pembelajaran serta menemukan pemecahannya. Sehingga, dalam proses pembelajaran perlu adanya sebuah regulasi berpikir yang dirancang oleh guru. Menurut Aministich (2012) menuliskan bahwa penalaran sering juga disebut jalan pikiran. Sedangkan metakognitif diartikan 
sebagai berpikir tentang berpikir. Weinert dan Kluwe (1987) menyatakan bahwa metakognisi adalah second-order cognition yang memiliki arti berpikir tentang berpikir, pengetahuan tentang pengetahuan, atau refleksi tentang tindakan-tindakan. Penalaran berkaitan erat dengan cara manusia untuk dapat menyimpullkan sesuatu. Penalaran untuk memecahkan masalah merupakan bagian dari berpikir. Dengan menggunakan penalaran maka suatu masalah akan bisa dipecahkan dan diperoleh solusinya.

Rangkaian pembelajaran yang dirancang mulai dari pengamatan sampai menarik kesimpulan merupakan kegiatan yang harus dilalui siswa. Untuk dapat mencapai hal tersebut, maka pembelajaran IPA dapat diwadahi melalui kegiatan laboratorium. Melalui kegiatan laboratorium IPA, siswa dilatih untuk dapat menggunakan pikiran secara sadar pada saat pembelajaran berlangsung dengan mengacu pada lembar kegiatan siswa berbasis metakognisi. Permasalahan yang muncul dalam kegiatan laboratorium IPA merupakan jembatan bagi siswa untuk dapat menggunakan jalan pikirannya melalui diskusi kelompok agar dapat mencari solusi terhadap masalah yang dihadapi.

\section{Rumusan Masalah}

Bagaimanakah kemampuan siswa pada elemen bernalar mengantisipasi serta mencari solusi terhadap masalah melalui metakognisi?

\section{Tujuan}

Untuk mengetahui kemampuan bernalar siswa pada indikator mengantisipasi serta mencari solusi terhadap masalah melalui metakognisi

\section{METODE PENELITIAN}

\section{Jenis Penelitian}

Penelitian ini merupakan penelitian mixed method yang menggunakan metode pengumpulan data secara kualitatif dan kuantitatif. Pengambilan data dilakukan secara simultan selama proses pengembangan pembelajaran dengan pendekatan metakognitif. 


\section{Desain Penelitian}

Desain penelitian ini adalah Research and Development (R \& D).

\section{Subjek Penelitian}

Subjek penelitian adalah siswa kelas VII SMP N 15 Kota Semarang.

\section{Instrumen Penelitian}

Instrumen perangkat pembelajaran Fisika dengan metakognisi untuk mengetahui kemampuan bernalar siswa pada indikator mengantisipasi serta mencari solusi terhadap masalah melalui metakognisi.

\section{Metode Analisis Data}

Analisis data dilakukan dengan menggunakan triangulasi mixmethod design yaitu dengan menganalisis secara simultan dari data kuantatif dan data kualitatif serta data gabungan. Selanjutnya menggunakan hasil analisisnya untuk memahami permasalahan penelitian.

\section{HASIL DAN PEMBAHASAN}

Pada proses pembelajaran di laboratorium IPA, desain lembar kerja siswa dirancang dengan urutan kegiatan yang memperlihatkan video yang berisi tentang diskusi materi campuran. Di awal kegiatan, siswa diberikan lembar kerja siswa yang memuat indikatorindikator dalam elemen bernalar (elemen berpikir kritis) versi Paul dan Elder yang disesuaikan dengan konsep pembelajaran. Pada saat video diputar, siswa melakukan diskusi kelompok dengan memperhatikan lembar kerja siswa yang meliputi: 1) Informasi yang didapatkan dari pengamatan video, 2) menghubungkan informasi dari video dengan kegiatan laboratorium yang akan dilakukan, 3) memprediksi masalah atau kendala yang mungkin terjadi dalam kegiatan praktikum penentuan campuran heterogen dan campuran homogen, 4) membuat rencana kegiatan praktikum sesuai dengan yang dipikirkan, 5) mengukur seberapa besar keyakinan saudara terhadap keberhasilan perencanaan yang dibuat bersama kelom- 
pok serta kemampuan dalam memberikan alasan, 6) melakukan kegiatan praktikum sesuai dengan perencanaan dengan catatan jika terjadi kesalahan dapat memberikan alasan serta dapat melakukan perbaikan.

Pada tahap awal pembelajaran, siswa memperhatikan video dan mendiskusikan hasil pengamatannya berdasarkan panduan pada lembar kerja siswa dengan berdiskusi. Dari hasil diskusi yang juga dipandu oleh guru, siswa menjadi terarah dalam melakukan kegiatan laboratorium IPA materi campuran.

Kemampuan berpikir kritis pada siswa dapat dilihat dari bagaimana siswa merespon setiap pertanyaan pada lembar kerja yang disajikan. Pada lembar kegiatan siswa nomor 6 yaitu siswa melakukan kegiatan praktikum sesuai dengan perencanaan dengan catatan jika terjadi kesalahan dapat memberikan alasan serta dapat melakukan perbaikan. Apa yang dituliskan siswa merupakan hasil pemikiran bersama dalam satu kelompok. Dari runtutan mengamati sampai dengan pengambilan kesimpulan, dilakukan secara bersama-sama dalam satu kelompok.

Salah satu aspek yang diungkap dalam kajian ilmiah ini yaitu tentang elemen bernalar: mengantisipasi serta mencari solusi terhadap masalah. Setiap kelompok menghadapi permasalahan yang berbeda-beda sesuai dengan yang dihadapi. Jika siswa merespon dengan menuliskan apa yang dihadapi dan dapat menuliskan solusi, maka dikatakan siswa telah berpikir, bersikap dan bertindak. Dalam pembelajaran, kegiatan diskusi yang dilakukan oleh siswa beragam. Berdasarkan pengamatan, beberapa siswa mampu menyelesaikan dengan mencoba langsung atau dengan kata lain langsung bertindak. Namun, aada juga yang bertanya-tanya melalui proses diskusi dengan teman satu kelompok tentang permasalahan yang dihadapi. Berikut tabel respon siswa terhadap lembar kerja siswa: 
Tabel 1. Respon Siswa terhadap Lembar Kerja Siswa No. 6

\begin{tabular}{|c|c|c|}
\hline Pertanyaan & Kelompok & Respon Siswa \\
\hline \multirow{6}{*}{$\begin{array}{c}\text { Lakukan } \\
\text { kegiatan } \\
\text { laborato- } \\
\text { rium sesuai } \\
\text { dengan ren- } \\
\text { cana yang } \\
\text { saudara } \\
\text { buat! (jika } \\
\text { terjadi } \\
\text { kesalahan, } \\
\text { berikan } \\
\text { alasan dan } \\
\text { perbai- } \\
\text { kan yang } \\
\text { seharusnya } \\
\text { dilakukan!) }\end{array}$} & 1 & Jika bahan tok dpt teraduk, aduk lbh keras \\
\hline & 2 & nggak ada yang salah \\
\hline & 3 & 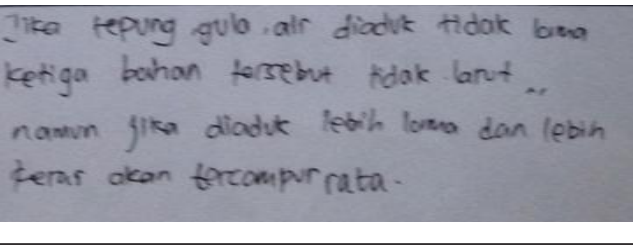 \\
\hline & 4 & $\begin{array}{l}\text { Mergantri curtuc mergambil } \\
\text { bahan karero banyar yang } \\
\text { membutuhken bahan }\end{array}$ \\
\hline & 5 & $\begin{array}{l}\text { Jika bahan Hidak bisa teraduk (larut) } \\
\text { adyklah lebih keras. }\end{array}$ \\
\hline & 6 & kesulitan untuk mendapatkan bahan. \\
\hline
\end{tabular}

Pada elemen bernalar: Konsep dengan indikator berpikir kritis mengaitkan hasil observasi dengan konsep, siswa merespon "dapat menghubungkan informasi" pada kegiatan laboratorium dengan menunjukkan serta membedakan antara campuran homogen dan heterogen. Hasil ini sesuai dengan yang ditulis oleh Arend (2009) bahwa berpikir kritis merupakan pengembangan cara berpikir secara mandiri tentang penyelesaian masalah. Di dalam kerja, siswa diminta untuk mencampurkan bahan-bahan yang telah tersedia. Dari hasil pencampuran, siswa dapat mengamati hasilnya apakah 
bahan yang dicampur termasuk dalam kategori campuran heterogen atau homogen. Konsep materi sebelumnya telah ditayangkan melalui video sebelum proses pencampuran dilaksanakan. Selanjutnya siswa mendefiniskan sendiri konsep dari campuran heterogen dan homogen. Keberhasilan siswa dalam membedakan campuran heterogen dan homogen dalam kegiatan laboratorium IPA melalui metakognisi merupakan hasil dari kegiatan penalaran. Melalui lembar kegiatan siswa (LKS) yang memuat elemen bernalar, siswa dapat memberikan solusi terhadap permasalahan yang dihadapi. Untuk dapat berpikir samppai dengan menyelesaikan permasalahan, guru mengarahkan siswa agar tetap fokus dalam kegiatan laboratoriumnya yaitu berpikir tentang apa yang sedang dilakukan. Hal tersebut senada dengan yang Djuanda (2008), bahwa siswa yang memiliki metakognitif yang baik, ia akan dapat memonitor dan mengarahkan proses belajarnya sendiri; ia juga memiliki kemampuan untuk menguasai informasi, dan menerapkan berbagai strategi belajar untuk memecahkan berbagai masalah dengan lebih mudah.

\section{SIMPULAN DAN SARAN}

Berdasarkan hasil penelitian dan pembahasan, dapat disimpulkan bahwa pembelajaran di kelas laboratorium IPA melalui metakognisi dapat meningkatkan kemampuan bernalar siswa pada indikator mengantisipasi serta mencari solusi terhadap masalah.

Sedangkan saran yang dapat penulis berikan yaitu guru dapat menerapkan metakognisi dalam meningkatkan penalaran siswa melalui kegiatan yang melibatkan siswa secara langsung. 


\section{DAFTAR PUSTAKA}

Aministich. 2012. Kemampuan Penalaran. On line. http://id.shvoong. com/social-sciences/ education/2252675-kemampuanpenalaran/\#ixzz3A36ndYkD. Diakses 11 Agustus 2013

Arend, Bridget. 2009. Encouraging critical thinking in online threaded discussions. The Journal of Educators Online, 6/1: 1-23.

Djuanda, Moh. 2008. Urgensi Metakognitif Dalam Meningkatkan Mutu Pembelajaran Di Madrasah. On line. http://bdkjakarta. kemenag.go.id/index.php?a=artikel\&id=884. Diakses 13 juli 2014

Flavell, J. (1979). Metacognitive and cognitive monitoring: A new area of cognitive developmental inquiry. American Psychologist. 34. 906-911.

Permendikbud Nomor 81a Tahun 2013

Suparno, P. 2006. Filsafat Konstruktivisme dalam Pendidikan. Yogyakarta: Kanisius.

Weinert, F. E. dan Kluwe, R. H. 1987. Metacognition, Motivation, and Understanding. Hillsdale, New Jersey: Lawrence Erlbaum Associates Publishers. 